Gut, 1986, 27, 838-843

\title{
Gut endocrine cell population in coeliac disease estimated by immunocytochemistry using a monoclonal antibody to chromogranin
}

\author{
R PIETROLETTI, A E BISHOP, F CARLEI, M BONAMICO, R V LLOYD, \\ B S WILSON, A CECCAMEA, E LEZOCHE, V SPERANZA, \\ AND J M POLAK \\ From the Department of Histochemistry, Royal Postgraduate Medical School, London, $6^{\circ}$ Clinica Chirurgica, \\ Policlinico Umberto $1^{\circ}$, Rome, Clinica Pediatrica, Policlinico Umberto $1^{\circ}$, Rome, Italy, University of \\ Michigan Medical School, Ann Arbor, Michigan, USA and Dipartimento di Biopatologia Umana, \\ Policlinico Umberto $1^{\circ}$, Rome, Italy.
}

SUmmary Abnormalities of gut endocrine responses, as well as changes in the number of different endocrine cell types, have been reported convincingly in coeliac patients. Nevertheless, no estimation of total numbers of gut endocrine cells has yet been made in well defined groups of coeliacs. In this study, we have visualised all endocrine cell types in jejunal biopsies from coeliac patients with active and quiescent disease as well as in controls, using a monoclonal antibody to chromogranin. This protein was purified originally from bovine adrenal medulla and is known to be a reliable marker for all endocrine cells of the gut. The following groups were considered: (a) nine coeliacs with active illness, (b) 10 coeliacs under gluten-free diet, (c) eight coeliacs receiving gluten challenge, (d) five non-coeliacs (controls). Histological (haematoxylin and eosin) and immunocytochemical (peroxidase anti-peroxidase) stains were applied to $3 \mu \mathrm{m}$ paraffin sections. Quantitative estimation of endocrine cell density was made using four different methods in order to evaluate the results fully (number of cells $/ \mathrm{mm}^{2}$, number of cells/visual field, number of cells $/ 8$ crypts-villi, number of cells/unit of length of muscularis mucosae). In patient groups (a) and (c), coeliacs with active disease and coeliacs on gluten challenge diet respectively, a significantly higher number of endocrine cells was observed in comparison with normal controls (group d). In group (b) patients, coeliacs on gluten-free diet, no significant changes in the number of endocrine cells were observed in comparison with controls. Our results show that a significant increase in endocrine cell density exists in coeliacs with active illness (groups a and c), in comparison with controls. This condition is resolved in coeliacs receiving a gluten-free diet (group b).

Abnormalities of both the number of endocrine cells of the jejunal mucosa and the plasma and tissue content of regulatory peptides have been observed in coeliac patients. ${ }^{1-8}$ The results are somewhat contradictory because some of them were obtained from adult patients receiving longstanding therapy, ${ }^{12}$ others from infants with short course disease. ${ }^{3}$ Also, some endocrine disturbances, such as abnormally high plasma enteroglucagon

Address for correspondence: J M Polak. Department of Histochemistry, Royal Postgraduate Medical School. Du Cane Road. London W12 0HS.

Received for publication 11 October 1985. concentrations, ${ }^{6}$ seem to return to normal after effective dietary therapy. An abnormal status of the endocrine system of the gut has been indicated to play a role in the pathophysiology of this disease, although no estimation of total numbers of gut endocrine cells has been made in well defined groups of coeliac patients.

Some proteins appear to be contained in all endocrine cell types, regardless of their product(s) and the immunochemical detection of these proteins represents an important tool for the visualisation and morphological analysis of entire endocrine components in physiological as well as pathological conditions. Chromogranin is a large, soluble protein 
originally purified from bovine adrenal medulla ${ }^{9}$ where it appears to be stored and released together with catecholamines. ${ }^{10} 11$ More recent studies have revealed that chromogranin is also present in polypeptide-producing human tumours as well as in normal endocrine tissues including the endocrine cells of the gut. ${ }^{12} 15$ Chromogranin is thus a useful marker for the latter.

In this study, we have visualised all endocrine cell types present in jejunal biopsies from paediatric coeliac patients, using a monoclonal antibody to chromogranin. In addition, we have assessed their numbers at different clinical stages of the illness, comparing the results with those obtained from non-coeliac patients, in order to establish if the entire endocrine cell population is modified, and we have studied the relationships between these changes and the alterations occurring in the nonendocrine component of the mucosa.

\section{Methods}

PATIENTS

Samples of small intestinal mucosa were obtained, with a Watson paediatric capsule placed at the ligament of Treitz, from the following subjects: group (a): Nine coeliac patients (two boys, seven girls, aged 2-10 years) presenting the clinical symptoms and laboratory data of coeliac disease. This diagnosis was supported by the observation of the histological features of active coeliac disease in the biopsies. At the time of the first biopsy, these patients had never been on a gluten-free diet.

Group (b): Ten coeliac patients (three boys, seven girls, aged 4-11 years) with a previous diagnosis of coeliac disease. These patients were biopsied after 13-15 months on a gluten-free diet and had shown a significant improvement, including regrowth of small intestinal villi.

Group (c): Eight coeliac patients (three boys, five girls, aged 3-5 years) with a previous history of coeliac disease established also on the basis of clinical, laboratory, and histological data and successfully treated by a gluten-free diet for a period of about 12 months. These patients then received a gluten challenge for a period of three to 24 months in order to verify the diagnosis and the efficacy of the therapy undertaken.

Coeliac disease was diagnosed according to the criteria laid down by the European Society of Paediatric Gastroenterology. ${ }^{16}$

Group (d): Five age-matched subjects (three boys, two girls, aged 6-12 years) with short stature or chronic non-specific diarrhoea and a suspected diagnosis of coeliac disease, who were found at biopsy to have a normal small intestinal mucosa.
All specimens were fixed routinely for about 24 hours in buffered formalin $\left(4 \times 10^{-3} \mathrm{Kg}\right.$ formaldehyde/100 cc PBS), dehydrated and embedded in paraffin wax (MP 333.15K). Routine histological staining (haematoxylin-eosin) was carried out for each sample.

\section{IMMUNOCYTOCHEMISTRY}

The sections were cut at $3 \mu \mathrm{m}$, perpendicular to the mucosal surface and then the peroxidase antiperoxidase method ${ }^{17}$ was applied. Sections were dewaxed through xylene and graded alcohols and brought to water. Endogenous peroxidase activity was removed by immersion in hydrogen peroxide in phosphate buffered saline ( $3 \mathrm{cc} \mathrm{H}_{2} \mathrm{O}_{2} / 100 \mathrm{cc}$ PBS $\mathrm{pH} 7 \cdot 2$ ) for 30 minutes.

The primary antibody to human chromogranin, obtained from the supernatant of a monoclonal cell live mouse hybridoma, ${ }^{18}$ was diluted $1: 25$ in PBS and applied to the sections for 16 hours at $4^{\circ} \mathrm{C}$ in a moist chamber. The sections were washed thoroughly in PBS and a second layer rabbit antimouse antibody (Miles) diluted 1:100 was applied for one hour at room temperature. After further washing, the monoclonal mouse PAP complex (SternbergerMeyer Immunochemicals), diluted 1:500, was incubated with the sections for one hour at room temperature. Then the sections were rinsed in PBS and the specific sites of immunoreactions were visualised by 3.3 diaminobenzidine $\left(25 \times 10^{-6} \mathrm{Kg} /\right.$ $100 \mathrm{cc} \mathrm{PBS} / 60 \times 10^{-3} \mathrm{cc} \mathrm{H}_{2} \mathrm{O}_{2}$ ). A light nuclear counterstain was obtained with diluted haematoxylin and finally the sections were dehydrated and mounted in permanent medium (DPX).

\section{QUANTIFICATION}

Quantification of the results was carried out on perpendicularly orientated sections, consisting of the entire thickness of the mucosa. A series of counts was made using different parameters, as previously described in similar studies, 12419 in order to validate fully the data obtained. We adopted the method of quantification per unit area, counting the immunoreactive cells only in the non-villous region of the mucosa of controls so that a direct comparison could be made with the sections which showed villous atrophy. In the quantification per visual field, chromogranin-immunoreactive cells were counted in 5-10 microscope fields $(\times 10$ objective of a Leitz-Orthoplan microscope) in three sections of each biopsy. We also evaluated the number of cells per eight crypt-villus units and the number of cells per unit length of muscularis mucosae using in the latter a graticule orientated parallel to the muscularis mucosae and counting all the immunoreactive nucleated cells of the epithe- 
lium. Mean values and the standard errors of the means were calculated. An analysis of variance was made using an f-test and, subsequently, Scheffe's test.

\section{CONTROLS}

Controls were undertaken in order to verify the specificity of the staining. They included omission of the primary antiserum or its substitution with non-immune serum. Absorption controls were also done using the diluted primary antiserum preabsorbed with an excess of antigen $(1 \mathrm{nmol} / \mathrm{ml}$ diluted antiserum). All of these controls gave no immunostaining, thus indicating the specificity of the immunoreactions.

\section{Results}

HISTOLOGY

Subtotal villous atrophy and the presence of mononuclear inflammatory cells in the lamina propria were constantly observed in group (a) as well as in group (c) patients (Fig. 1). Partial to complete normalisation of the histological parameters was observed in group (b) patients, while group (d) revealed normal morphology of the intestinal mucosa.

\section{IMMUNOCYTOCHEMISTRY}

Immunostained cells were observed mainly in the midportion of the crypts, and these were far more numerous in groups (a) and (c) (Fig. 2). Scattered immunoreactive cells were also present in the villi (Fig. 3), observed predominantly in groups (b) and (d). Nervous structures present in the lamina propria were unstained. The density of endocrine cells for each group is shown in the Table. The analysis of variance (f-test) revealed statistically significant differences in the results for each group $(p<0.01)$. A multiple comparison was therefore carried out using Scheffe's test. All four quantitative methods used showed that the active coeliacs (group a) and the coeliacs receiving gluten-challenge (group c) had significantly more endocrine cells than the normal controls (Table).

Comparison between the morphological features of the disease, villous atrophy and lymphocytic infiltration, and endocrine cell density revealed no obvious relationship.

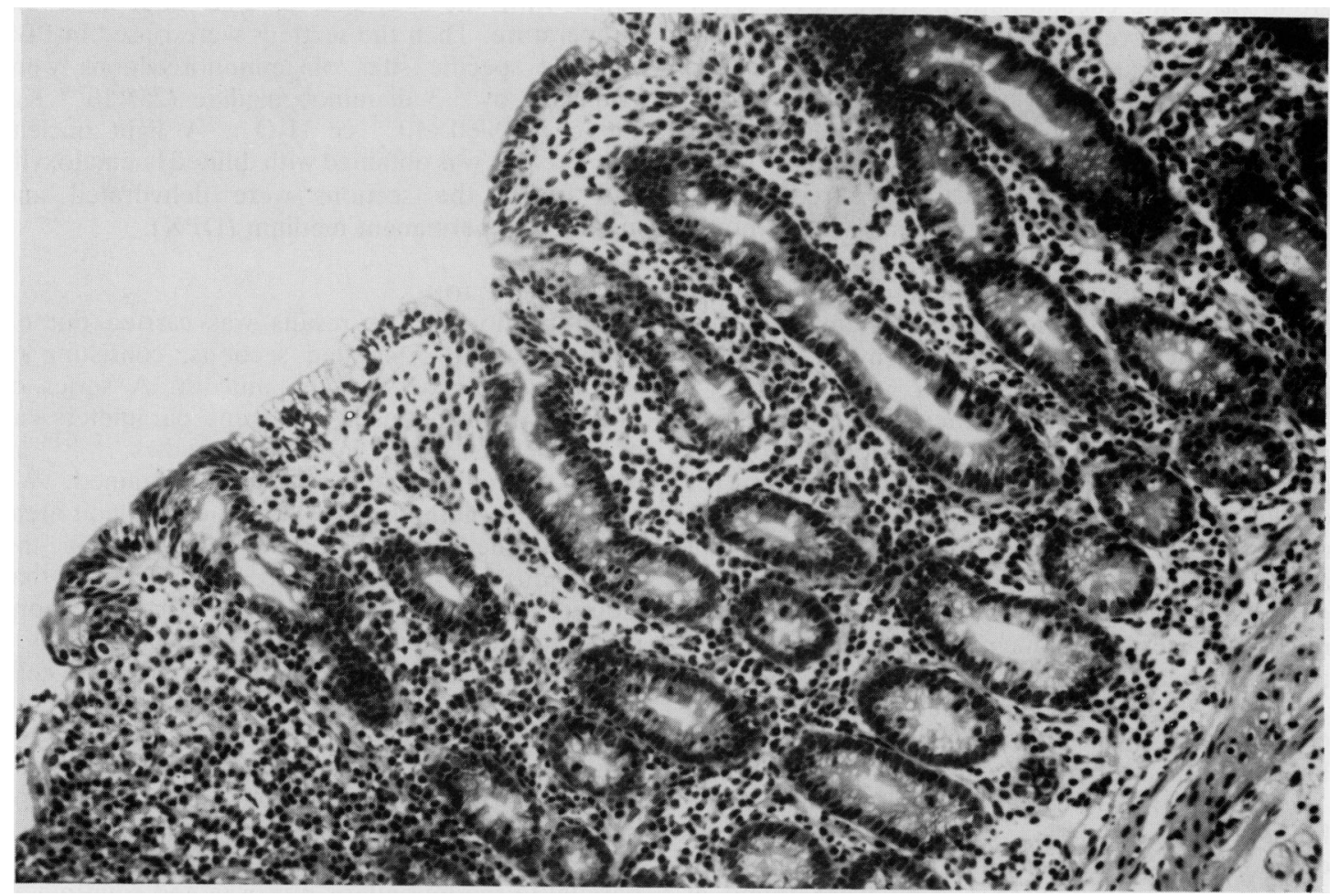

Fig. 1 Haematoxylin-eosin staining of a biopsy from a patient of the group (a) showing features of active coeliac disease. 


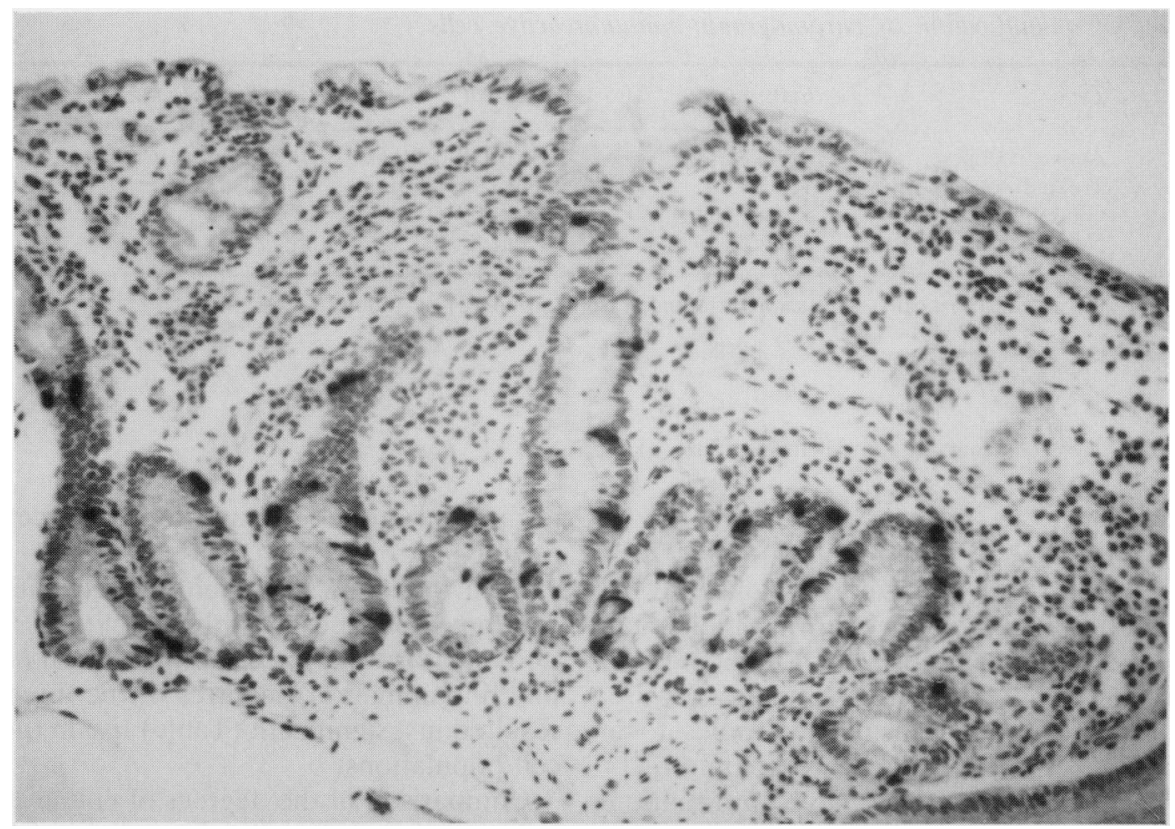

Fig. 2 Numerous chromogranin-immunoreactive cells in the mucosal crypts of a biopsy from a patient with active coeliac disease (group a).

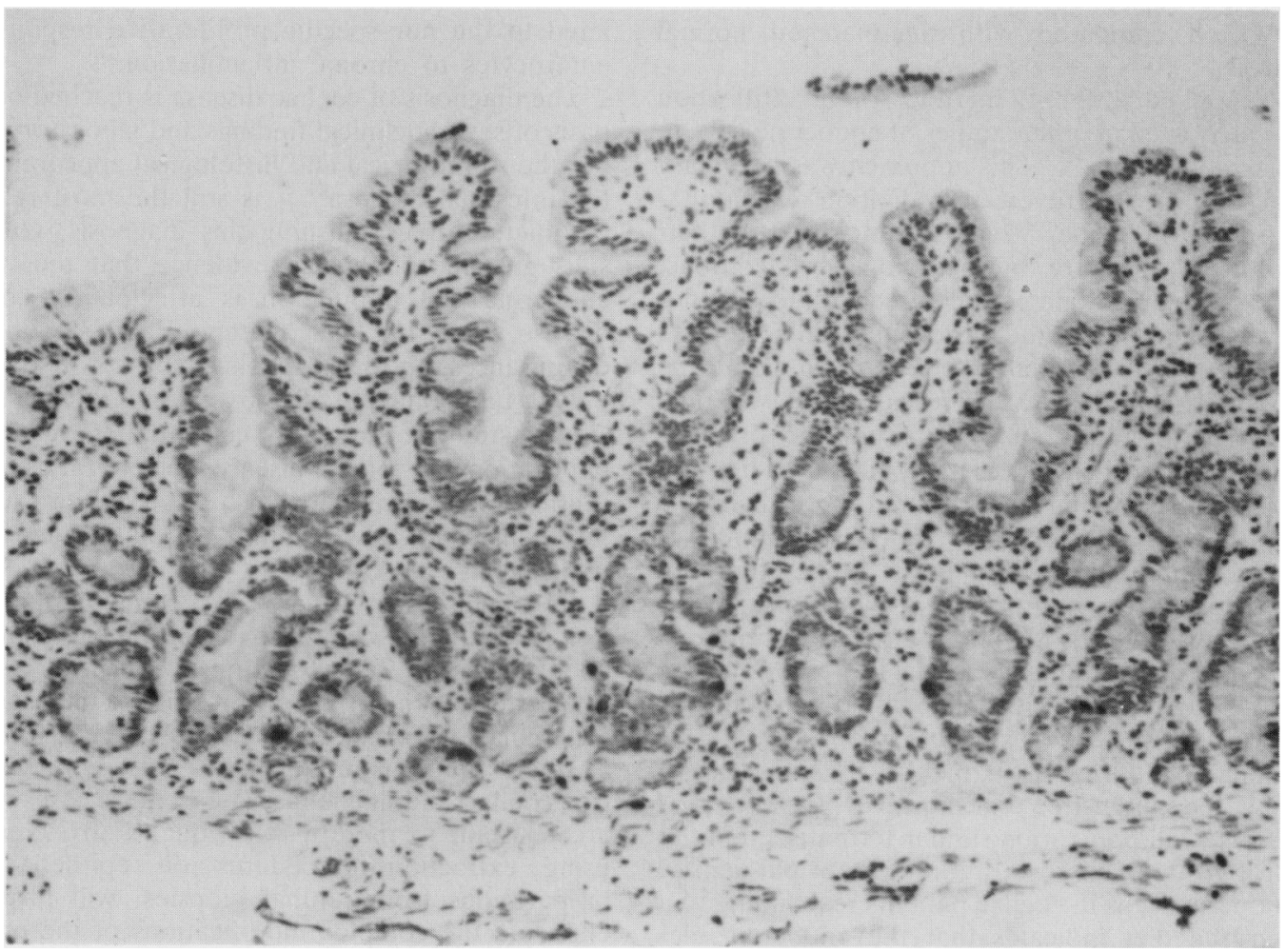

Fig. 3 Normal numbers of chromogranin-immunoreactive cells in the villi and crypts of a biopsy from a control patient (group d). 
Table Results of quantification of chromogranin-immunoreactive cells

\begin{tabular}{llllc}
\hline Group & Type & Cells $/ \mathrm{mm}^{2}$ & Cells/field & Cells/8 crypt-villus \\
\hline A & Active coeliacs & $84 \cdot 8 \pm 36 \cdot 6 \ddagger$ & $59 \cdot 4 \pm 10 \cdot 8 \dagger$ & $20 \cdot 2 \pm 2 \cdot 6 \$$ \\
B & Treated coeliacs & $41 \cdot 6 \pm 13 \cdot 9$ & $25 \cdot 6 \pm 15 \cdot 3$ & $11 \cdot 6 \pm 1 \cdot 6$ \\
C & Gluten-challenge & $82 \cdot 5 \pm 34 \cdot 1 \ddagger$ & $52 \cdot 8 \pm 14 \cdot 9^{*}$ & $21 \cdot 2 \pm 2 \cdot 8 \S$ \\
D & Normal controls & $42 \cdot 8 \pm 27 \cdot 1$ & $16 \cdot 3 \pm 2 \cdot 8$ & $22 \cdot 4 \pm 4 \cdot()$ \\
\hline
\end{tabular}

Groups (a) and (c) showed statistically significant differences from group (d) as follows:-

${ }^{*} \mathrm{p}<0 \cdot 05$

$+\mathrm{p}<0 \cdot 01$

$\neq \mathrm{p}<0 \cdot 005$

$\S \mathrm{p}<0 \cdot 001$

Group (b) showed no significant differences from group (d).

\section{Discussion}

Coeliac disease has been reported previously to be associated with changes in the various individual types of gut endocrine cells. ${ }^{1-4}$ In the present study, entire gut endocrine cell populations were examined in tissue sections using antibodies to a general marker for these cells, chromogranin. ${ }^{9-15}$ Furthermore, in order to obtain more information on the relationship between the course of the disease and the changes in endocrine cells, three separate groups of coeliac children were selected for study and compared with age-matched normal controls.

We applied different methods of quantification previously used in other studies of endocrine cells in coeliac disease. ${ }^{12+19}$ This approach was necessary because of the controversial evaluation of quantitative results in tissues which are modified in their histological structure by pathological conditions. The expression of data per unit area of mucosa is not the most suitable method as oedema and lack of villi may modify substantially the dimensions of the biopsy in coeliac disease. The use of cells/visual field quantification does not differ from the previous method, as it still considers number of cells per unit of area. Most suitable methods are those which have been used in other studies, ${ }^{419}$ where the number of cells is evaluated per unit length or per morphological unit - for example, crypt-villus unit. In the present study, all the methods of quantification used showed a significant increase in the enteric endocrine cells of coeliacs with active disease, in comparison with normal controls (Table).

Coeliac children who had been treated successfully with a gluten-free diet, however, showed a gut endocrine cell population similar to that seen in the control group. This restoration of a normal density of endocrine cells in coeliac patients responding to a gluten-free diet indicates that the endocrine elements, as well as the enterocytes, ${ }^{20}$ modify their turnover in active illness, while they return to normal mitotitic activity after an effective dietary regime.

Reintroduction of gluten into the diet of coeliac children produced not only the clinical (malabsorption, steatorrhoea) and morphological (villous atrophy, inflammation) features of the disease but also resulted in a significant (Table) rise in the endocrine cell populations.

Comparison of the degrees of villous atrophy and inflammation with endocrine cell numbers revealed no relationship, suggesting that the endocrine cell changes in untreated coeliac disease may be unrelated to the non-specific proliferative response of enterocytes to chronic inflammation. ${ }^{21}$

The diagnosis of coeliac disease is reached on the basis of several clinical findings and laboratory data but the stereological and histological appearance of the intestinal mucosa ${ }^{21} 22$ is still the most reliable parameter for establishing this diagnosis. Our results give morphological evidence that the whole endocrine cell population is affected by coeliac disease and that the metabolic and endocrine disturbances reported in coeliac patients are due not only to functional but also to anatomical changes. A similar study of endocrine cell numbers may have applications in other diseases where atrophy of jejunal mucosa and malabsorption occur such as intolerance to cow's milk, giardiasis, and iron deficiency. ${ }^{23}$

In conclusion, it seems that a complex modification of endocrine cell turnover takes place in active coeliac disease. These changes, which disappear after effective therapy, may give rise to the reported functional disturbances in gut hormone release..$^{5-8}$ Further studies on gut hormone responses in glutenfree coeliacs, adult coeliacs and in those cases which are resistant to therapy, with quantitative analysis using extraction procedures on epithelial cell preparations from jejunal biopsies, will probably elucidate the complex modifications of the enteric neuroendocrine system which take place in this disease. 


\section{References}

1 Sjöklund K, Alumets J, Berg NO, Hakanson R, Sundler F. Enteropathy of coeliac disease in adults: increased number of enterochromaffin cells in the duodenal mucosa. Gut 1982; 23: 42-8.

2 Sjöklund K, Alumets J, Berg N O, Hakanson R, Sundler F. Duodenal endocrine cells in adult coeliac disease. Gut 1979; 20: 547-52.

3 Polak JM, Pearse AGE, Van Noorden S, Bloom SR, Rossitter MA. Secretin cells in coeliac disease. Gut 1973; 14: 870-4.

4 Buchan AMJ, Grant S, Brown JC, Freeman HJ, A quantitative study of enteric endocrine cells in celiac sprue. J Paediatr Gastroenterol Nutr 1984; 3: 665-71.

5 Besterman HS, Bloom SR, Sarson DL et al Gut hormone profile in coeliac disease. Lancet 1978; I: 785-8.

6 Kilander AE, Dotevall G, Lindstedt G, Lundberg GP Plasma enteroglucagon related to malabsorption in coeliac disease. Gut 1984; 25: 629-35.

7 O’Connor FA, McLoughlin JC, Buchanan KD. Impaired immunoreactive secretin release in coeliac disease. Br Med J 1979; 1: 811-2.

8 Dawson J, Bryant MG, Bloom SR, Peters TJ. Gastrointestinal regulatory peptide storage granule abnormalities in jejunal mucosa disease. Gut 1984; 25: 636-3.

9 Smith AD, Winkler H. Purification and properties of an acidic protein from chromaffin granules of bovine adrenal medulla. Biochem J 1967; 103: 483-92.

10 Schneider FH, Smith AD, Winkler H. Secretion from the adrenal medulla biochemical evidence for exocytosis. Br J Pharmacol Chemother 1967; 31: 94-104.

11 Blaschko H, Comline RS, Schneider FH, Silver M Smith AD. Secretion of a chromaffin granule protein, chromogranin, from the adrenal gland after splanchnic stimulation. Nature 1967; 215: 58-9.

12 O Connor DT, Burton D, Deftos LJ. Immunoreactive human chromogranin $\mathrm{A}$ in disease polypeptide hor- mone producing human tumours and normal endocrine tissues. J Clin Endocrinol Metab 1983; 57: 1084-6.

13 Facer P, Bishop AE, Lloyd RV, Wilson BS, Hennessy RJ, Polak JM. Chromogranin: a newly recognised marker for endocrine cells of human gastrointestinal tract. Gastroenterology 1985; 89: 1366-73.

14 Wilson BS, Lloyd RV. Detection of chromogranin in neuroendocrine cells with a monoclonal antibody. $\mathrm{Am}$ J Pathol 1984: 115: 458-68.

15 Lloyd RV, Mervak T, Schmidt K, Warner TFCS, Wilson BS. Immunohistochemical detection of chromogranin and neuron specific enolase in pancreatic endocrine neoplasms. Am J Surg Pathol 1984; 8: 6()7-14.

16 Meeuwise GW. Diagnostic criteria in coeliac disease. Acta Paediatr Scand 1970; 59: 461-3.

17 Sternberger LA Immunocytochemistry. New York: Prentice Hall, 1979.

18 Lloyd RV, Wilson BS. Specific endocrine tissue marker defined by a monoclonal antibody. Science 1983; 222: 628-30.

19 Marsh MN. Studies on intestinal lymphoid tissue. III-Quantitative analysis of epithelial lymphocytes in the small intestine of human control subjects and of patients with coeliac disease. Gastroenterology 1980; 79: 481-92.

20 Booth CC. Enterocyte in coeliac disease, I \& II. Br Med J 1970; iii: 725-731 and iv: 14-17.

21 Marsh MN. Studies of intestinal lymphoid tissue. IV The predictive value of raised mitotic indices among jejunal epithelial lymphocytes in the diagnosis of gluten-sensitive enteropathy. J Clin Pathol 1982; 35: 517-25.

22 Marsh MN, Haeney MR. Studies on intestinal lymphoid tissue. VI Proliferative response of small intestinal epithelial lymphocytes distinguishes gluten-from non-gluten-induced enteropathy. J Clin Pathol 1982; 36: $149-60$.

23 Walker-Smith J. Diseases of the small intestine in childhood. London: Pitman Medical, 1979. 